\title{
New localities of rare liverworts in the Central Poland
}

Monika Staniaszek-Kik

New localities of rare liverworts in the Central Poland. - Acta Mus. Siles. Sci. Natur., 63: 151-154, 2014.

\begin{abstract}
The present study reports new localities of four liverwort species, i.e., Fossombronia foveolata Lindb., Gymnocolea inflata (Huds.) Dumort., Leiomylia anomala (Hook.) J.J.Engel \& Braggins and Odontoschisma denudatum (Mart.) Dumort., found in Central Poland. The new sites are situated in peat bog habitats and swamp forest in the depression cone of lignite opencast mine near Bełchatów in Central Poland. All of the reported species are very rare and have only few localities in Central Poland.
\end{abstract}

Key words: liverworts, threatened species, depression cone, distributional data, Central Poland

\section{Introduction}

Central Poland, according to the borders proposed by Jakubowska-Gabara et al. (2011), encompasses the entire region of the Łódź voivodeship. Previous bryological studies conducted in this area, indicated a low diversity of bryophyte flora; in total 62 species of liverworts have been identified (Staniaszek-Kik \& Wolski, 2009). This may result from a significant transformation of the environment in the Łódź region, its low forest area, as well as the specifity of existing forests (fragmented forest complexes, dominance of pine in the stands) (Maksymiuk \& Olaczek, 2001). Furthermore, one of the largest in the country opencast lignite mine in Bełchatów is a factor with a significant impact on the environment of Central Poland (Czyżewska \& Olaczek, 1983). The establishment of the mine and associated formation of a depression cone, resulted in many changes of forest and non-forest phytocoenoses, peat bog phytocoenoses in particular (Kurowski, 1993; Balcerzak, 2003). On the other hand, rather poor bryophyte flora of Central Poland may also result from inadequate identification of their species. Although bryological studies in Central Poland have been conducted already at the beginning of the nineteenth century, this region still is considered to be poorly investigated in terms of diversity of mosses and liverworts (Staniaszek-Kik \& Wolski, 2009).

Four rare bryophyte localities have been found within the limits of the existing depression cone surrounding the mine Bełchatów in 2013, as part of the peat bogs monitoring programme. The aim of this study is to present their distribution in Central Poland.

\section{The species and their distribution}

1. Fossombronia foveolata Lindb. - In Poland, F. foveolata (Fig 1) is known from the localities throughout the country, but mainly in the lowland regions, especially in the northwestern area (Koła \& Turzańska 1995). The number of sites is greatly reduced in the southern and eastern Poland. This species is placed on the Red List under "E" category - endangered species (Klama 2006). Until now, this species has been identified in Central Poland at four localities: Dd85: Marysin III [currently a district of Łódź], forest peat bog (Chmielewski \& Urbanek 1963); Dd96: Modlica (Municipality Tuszyn), forest peat bog (Chmielewski \& Urbanek 1963, Urbanek 1966; LOD no 132, leg. T. Chmielewski 04.10.1954); Dd75: peat bog „Rąbień” near Aleksandrów Łódzki, on moist peat (Chmielewski \& Urbanek 1963, Urbanek 1966; LOD no 133, leg. T. Chmielewski 05.08.1956); Ed67: Rędziny (Municipality 
Żytno), edge of the forest peat bog (LOD no 134, leg. H. Urbanek 17.07.1962). New locality: Ed35: Huby Ruszczyńskie (Municipality Kamieńsk) N 51¹4'201” E19²5'636” (LOD no 837, 27.09.2013 leg. M. Staniaszek-Kik), species was found in the moist soil, on the edge of a small forest peat bog (post-peat overgrown pit).

2. Gymnocolea inflata (Huds.) Dumort. - a species known from numerous sites in the north and the south of Poland. This taxon is significantly less common in the lowlands of the central belt (Szweykowski 2006). Until now this species has been known in Central Poland from five localities: Ed23: the vicinity of the village Szczerców (Bełchatów County) (Urbanek-Rutowicz 1969); Ed67: Rędziny - Uroczysko Rędziny (Municipality Żytno) (Urbanek 1967); Żytno - Uroczysko Sowin (Radomsko County) (Urbanek 1967); Ee50: Ruda Pilczycka - Uroczysko Piskorzeniec (Końskie County) (Urbanek-Rutowicz 1969); Dd85: Marysin III [currently a district of Łódź], forest bordering the peat bog (Chmielewski \& Urbanek 1963, Urbanek 1966); Dd96: Tuszyn-Las [currently a district of Tuszyn], in the peat bog (Chmielewski \& Urbanek 1963, Urbanek 1966). New locality: Ed24: the vicinity of the village Żar (Municipality Kluki) N 51 '17'678” E 19¹1'220”' (LOD no 836, 02.10.2013 leg. M. Staniaszek-Kik), species was found on the mineral substrate, in the community of Rhynchospora alba on the edge of the peat bog.

3. Leiomylia anomala (Hook.) J.J.Engel \& Braggins - in Poland this taxon occurs mainly in the northern part of the country (particularly in Western and Central Pomerania) and the Sudetes and Carpathian Mountains. Until now, only single localities have been identified in the Polish central belt (Górski 2013). In Central Poland, three sites have been found so far: Dd75: peat bog "Rąbień" near Aleksandrów Łódzki (Chmielewski \& Urbanek 1963, Urbanek 1966); Dd96: Tuszyn-Las [now a district of Tuszyn], in the swamp pine forest (Chmielewski \& Urbanek 1963, Urbanek 1966); Ed67: the vicinity of the village Żytno - Uroczysko Żytno (Radomsko County) (Urbanek-Rutowicz 1969). New locality: Ed24: the vicinity of the village Trząs (Municipality Kluki), N 51¹7’503” E 19¹2’848” (LOD 835, 04.10.2013 leg. M. Staniaszek-Kik), taxon identified at the edge of the transitional peat bog, on the humus soil.

4. Odontoschisma denudatum (Mart.) Dumort. - taxon with isolated localities in Poland, but often listed only in the north-east and south-west regions (Sudetes) of our country (Szweykowski 2006). This species is under strict protection. In Central Poland this species is rather rare, found only at two localities: Ed67: the vicinity of the village Żytno - Uroczysko Żytno (Radomsko County) on rotting stumps (Urbanek-Rutowicz 1969); Ec17: areas of Węglewice cluster (Wieruszów County) on rotting stumps (Urbanek-Rutowicz 1969). New locality: Ed33: the vicinity of the village Rząśnia (Pajęczno County), N 51¹4'24.82” E 195'18.45” (LOD 834, 22.05.2013 leg. M. Staniaszek-Kik), on decaying tree stump in the dried swamp forest.

\section{Conclusions}

The present paper report new localities of four liverworts - Fossombronia foveolata, Gymnocolea inflata, Leiomylia anomala and Odontoschisma denudatum. These data from Central Poland are especially important because this region has been very poorly studied till now. The last records of these species from the Łódź Province were collected more than 40 years ago. Important is that all new localities are placed in the depression cone of lignite opencast mine near Bełchatów. As a result of mining of lignite using open-cast method the long-term and significant transformations of environment are ensued, including modifications of soil surface and hydrographic conditions. All these transformations are of great importance for destruction of liverworts habitats. Future studies which are planned for next years will allow to monitor condition of populations of these rare liverworts in mentioned area. 


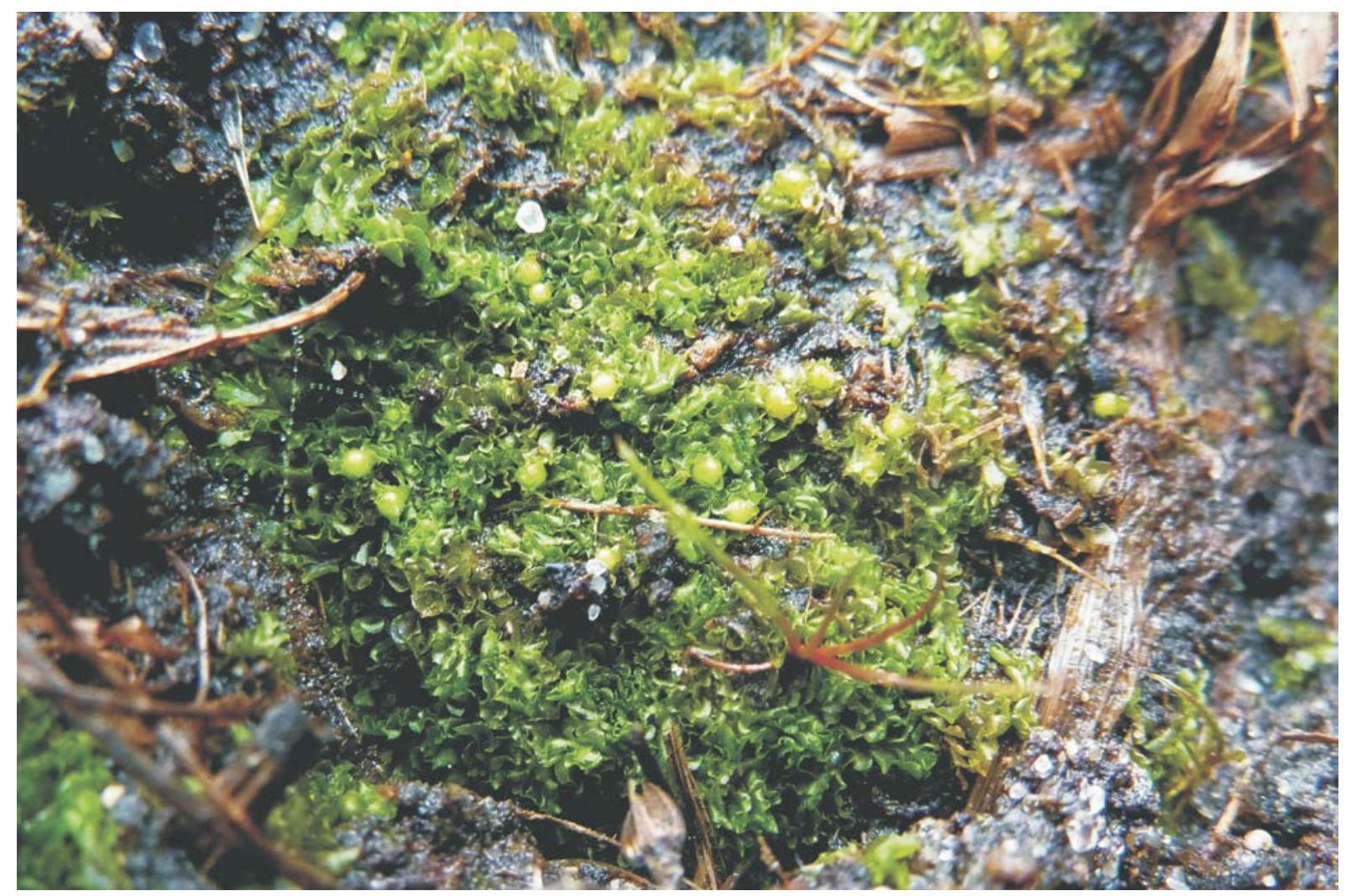

Fig 1: Pitted Frillwort Fossombronia foveolata with young sporophytes (Photo by Monika Staniaszek-Kik, $27^{\text {th }}$ September 2013).

\section{References}

Balcerzak P. (2003): Zmiany w szacie roślinnej Bełchatowskiego Okręgu Przemysłowego w II połowie XX w. (północno-wschodnia część BOP). Praca magisterska (manuscript), Uniwersytet Łódzki, Łódź.

Chmielewski T. \& Urbanek H. (1960): Mchy okolic Łodzi. - Łódzkie Towarzystwo Naukowe, Sprawozdanie z Czynności i Posiedzeń, 17(4): 1-16.

Chmielewski T. \& Urbanek H. (1963): Mszaki okolic Łodzi (wątrobowce i torfowce). - Łódzkie Towarzystwo Naukowe, Sprawozdanie z Czynności i Posiedzeń, 15(6): 1-18.

Czyżewska K. \& Olaczek R. (1983): Bełchatowski Okręg Przemysłowy w badaniach Instytutu Biologii Środowiskowej Uniwersytetu Łódzkiego. - Acta Universitatis Lodziensis Folia Sozologica, 1: 89-123.

Górski P. (2013): Wątrobowce (Marchantiophyta) Leśnego Kompleksu Promocyjnego „lasy Środkowopomorskie" (Pomorze Zachodnie). Nadleśnictwo Karnieszewice.

Jakubowska-Gabara J., Kucharski L., Zielińska K., Kołodziejek J., Witosławski P. \& Popkiewicz P. (2011): Atlas rozmieszczenia roślin naczyniowych w Polsce Środkowej. Gatunki chronione, rzadkie, ginące i narażone. Wydawnictwo Uniwersytetu Łódzkiego, Łódź.

Klama H. (2006): Red list of the liverworts and hornworts in Poland. In Mirek Z., Zarzycki K., Wojewoda W. \& Szeląg Z. (eds): Red list of plants and fungi in Poland. W. Szafer Institute of Botany, Polish Academy of Sciences, Kraków: 21-35

Koła W. \& Turzańska M. (1995): Wątrobowce (Hepaticopsida) i glewiki (Anthocerophytina). Klucz do oznaczania. Część I. Wątrobowce plechowate i glewiki. Wydawnictwo Uniwersytetu Wrocławskiego, Wrocław.

Kurowski J.K. (1993): Dynamika fitocenoz leśnych w rejonie kopalni odkrywkowej Bełchatów. Wydawnictwo Uniwersytetu Łódzkiego. Łódź.

Maksymiuk Z. \& Olaczek R. (2001): Indywidualność przyrodnicza regionu łódzkiego. In Liszewski S. (ed.): Funkcja regionalna Łodzi i jej rola w kształtowaniu województwa. Zarys monografii województwa łódzkiego. Łódzkie Tow. Nauk., Łódź: 49-51

Staniaszek-Kik M. \& Wolski G. J. (2009): Mszaki - zróżnicowanie, zmiany i zagrożenia. In Kurowski J. K. (ed.): Szata roślinna Polski środkowej. Towarzystwo Ochrony Krajobrazu, Wydawnictwo EKO-GRAF: 48-56. 
Szweykowski J. (2006): An annotated checklist of Polish liverworts and hornworts - Krytyczna lista wątrobowców i glewików Polski. Biodiversity of Poland 4. W. Szafer Institute of Botany, Polish Academy of Sciences, Kraków.

Urbanek H. (1966): Zespoły leśne województwa łódzkiego ze szczególnym uwzględnieniem mszaków. Cz. IV. Przegląd mszaków w wyróżnionych zespołach leśnych. - Fragmenta Floristica et Geobotanica Seria Polonica, 12(2): 151-178.

Urbanek H. (1967): Torfowiska okolic Żytna w powiecie radomszczańskim. - Zeszyty Naukowe Uniwersytetu Łódzkiego, Nauki Matematyczno-Przyrodnicze, Ser. II, 23: 61-73.

Urbanek-Rutowicz H. (1969): Udział i rola diagnostyczna mszaków oraz stosunki florystyczno fitosocjologiczne w przewodnich zespołach roślinnych regionu łódzkiego i jego pobrzeży. Wydawnictwo Uniwersytetu Łódzkiego, Łódź.

Author's address: Monika Staniaszek-Kik, Department of Geobotany and Plant Ecology, University of Łódź, Banacha 12/16, 90-237 Łódź, Poland, e-mail: kik@biol.uni.lodz.pl 